\title{
Impact of salinity and zinc application on growth, physiological and yield traits in wheat
}

\author{
Sonia Rani*, Manoj Kumar Sharma, Neeraj Kumar and Neelam
}

CCS Haryana Agricultural University, Hisar 125 004, India

\begin{abstract}
Globally salinity impairs the productivity potential of agricultural land. Apart from salinity, there are a number of factors responsible for the stagnation of wheat productivity. This problem is becoming acute day by day due to improper management of natural resources. Salinity has repressive effects on physiological characteristics of wheat. Soil salinity affects plant growth by creating water and ionic imbalance in the plant due to the presence of toxic ions. Salt-affected plants exhibit stunted growth and have darker leaf colour. Nutrient deficiency is another yield-limiting factor and this problem is aggravating gradually due to intensive cultivation, imbalanced and injudicious usage of fertilizers. The widespread deficiency of nitrogen and phosphorus is followed by $\mathrm{Zn}$ deficiency. Zinc is an important component of proteins and acts as a structural, functional or regulatory cofactor of a number of enzymes. Moreover, it plays a significant role in plant metabolism. Generally, the presence of excess salt decreases photosynthesis, total carbohydrate, fatty acid and protein, therefore, zinc has the tendency to offset the negative effects of salinity on plant growth.
\end{abstract}

Keywords: Growth and yield, salinity, wheat, zinc.

IN recent decades, cultivated areas have been badly influenced by ecological stresses such as salinity and drought in various parts of the globe, which suppress crop growth and productivity ${ }^{1}$. Soil salinization is a key factor leading to the loss of productivity of arable soils. Though hard to calculate precisely, the area under salinized soils is increasing, and this phenomenon is exceptionally extreme in irrigated areas. It was calculated that around $20 \%$ (45 million ha) of irrigated land, producing one-third of the world's food, is salt-affected ${ }^{2}$. Saline soil is formed when chlorides and sulphates of sodium, calcium, magnesium and potassium are copious in the soil. The USDA Salinity Laboratory describes saline soil as having an electrical conductivity of the saturation extract $\left(\mathrm{EC}_{\mathrm{e}}\right)$ of $4 \mathrm{dS} \mathrm{m}^{-1}$ or more. Apart from $\mathrm{EC}_{\mathrm{e}}, \mathrm{pH}$ and ESP (exchangeable sodium percentage) are also some of the quantitative parameters to define saline soil. It has $\mathrm{pH}$ value $<8.5$, exchangeable sodium percentage $(\mathrm{ESP})<15$ and sodium absorption ratio $(\mathrm{SAR})<10$. Salt accretion in the root zone causes development of osmotic stress and disturbs cell ion homeostasis by inducing both the inhibition in

\footnotetext{
*For correspondence. (e-mail: sonia.sagwal18@gmail.com)
}

the uptake of essential elements like $\mathrm{K}^{+}, \mathrm{Ca}^{2+}$ and $\mathrm{NO}^{3-}$ and the accumulation of $\mathrm{Na}^{+}$and $\mathrm{Cl}^{-}$ions ${ }^{3}$. It is anticipated that these ecological stresses will turn more extreme and frequent in time to come. On the contrary, the world population is presumed to reach about 10 billion by 2050, which will experience grave food shortages $^{4}$. Thus, the development of schemes to alleviate the adverse effects of ecological stresses have received significant attention. Salinity is one of the severe agrarian and environmental issues in arid and semi-arid areas which detrimentally affect crop growth and agricultural productivity $^{5-7}$, thereby affecting $19.5 \%$ of irrigated and $2.1 \%$ of dry land agriculture at global scale ${ }^{8}$. Despite the fact that soil salinity occurred prior to the dawn of agriculture, the salinity problem in soils is currently increasing at an annual rate of $10 \%$ (ref. 2). Researchers have figured that more than $50 \%$ of the earth's cultivable land could be salinized by 2050 (refs 9-11). The total area of salt-affected soils across the globe is $932 \mathrm{~m} \mathrm{ha}$, of which 351 and $581 \mathrm{~m}$ ha is saline and sodic respectively ${ }^{12}$. In India total salt affected area is $6.74 \mathrm{~m}$ ha out of which 3.79 and $2.95 \mathrm{~m}$ ha are of sodic and saline soils respectively, whereas $0.49 \mathrm{~m}$ ha is the area affected by saline soil in Haryana. The maximum area under salt-affected soils is in Gujarat (2.22 $\mathrm{m} \mathrm{ha}$ ) followed by Uttar Pradesh (1.37 m ha).

Salinity is one of the most crucial abiotic stresses, which inhibits crop production in arid and semi-arid areas, as those contain adequate salt in the root zone to alter the growth of crops. Besides, low precipitation is inadequate for leaching these salts below root zone levels ${ }^{13}$. Excessive soluble salts in the root zone inhibit plant roots from withdrawing water from neighbouring soil, practically reducing the plant available water ${ }^{14}$. As a result, soil salinity has the capability to alter plant growth through higher concentrations of toxic ions present in the soil ${ }^{15}$. Specific ion toxicities are caused by the accumulation of sodium, chloride and boron in the tissue of transpiring leaves to damaging levels. Accrual of harmful ions might hinder photosynthesis and protein synthesis; inactivate enzymes, and injure chloroplasts and other organelles ${ }^{16}$. These effects are more critical in older leaves, as they have been transpiring the longest, so they accrue more ions ${ }^{17}$. The most influencing ions of saline soils are $\mathrm{Na}^{+}$ and $\mathrm{Cl}^{-}$which affect the cell membrane by interaction, competition and selectable ion penetration and disorder 
on the absorption of macro and micro elements ${ }^{18}$. Salts damage cells of plants and inhibit their growth. The damage is because of different types of oxygen activation radicals that are toxic and activators for their cells ${ }^{19}$. The distribution of plants, their survival and productivity are distinctly influenced by salinity ${ }^{20,21}$.

Salt stress influences plant physiology of the whole plant besides at the cellular level, through osmotic and ionic stress which creates a physiological drought or osmotic stress by disturbing the water relations of the plant $^{22}$. Generally, the cultivated plants are sensitive to salt-stress, in which sodium chloride $(\mathrm{NaCl})$ causes a diminution in carbohydrates that are required for cell growth. Carbohydrates are synthesized largely through the process of photosynthesis and photosynthetic rates are generally lower in plants exposed to salinity and particularly to $\mathrm{NaCl}^{20,23}$ and this would cause a restriction in water availability and imbalance in nutrient uptake by plants with inhibition in seed germination owing to ionic disturbance, osmotic and toxic effects. Ion exclusion, ion sequestration, osmotic regulation and membrane transport system adjustment to saline environments are principal strategies that may confer salt tolerance to plants ${ }^{24}$. Alloway $^{25}$ observed that zinc is a trace element required in small but critical concentrations and if the quantity available is not sufficient, plants will undergo physiological stress caused by the dysfunction of various enzyme systems and other metabolic functions in which $\mathrm{Zn}$ plays a part. Maischner ${ }^{26}$ suggested that zinc is an indispensable constituent of over 300 enzymes. Zinc is known to have a crucial function either as a metal component of enzymes or as a functional, structural or regulatory cofactor of a multitude of enzymes. Zinc is a basic component of a number of enzymes, i.e. dehydrogenase, isomerases, aldolase, proteinase, peptidase and phosphohydrolase ${ }^{27}$. A meagre amount of nutrients, especially $\mathrm{Zn}$ applied by foliar spray, enhances the yield of crop significantly ${ }^{28}$. Zinc fertilizer alleviates the adverse effects on physiological and biochemical parameters in sensitive and tolerant varieties of wheat genotypes in the saline soil environment. Soil salinity adversely affected the relative water content (RWC), transpiration rate, protein, carbohydrate and starch content but diffusive resistance increased significantly in the wheat genotypes at tillering and ear emergence stage ${ }^{29}$. Wheat is the most widely cultivated food crop of the world. In India, wheat is the second most staple food crop. In the light of the role of zinc application and salinity on growth and nutrient content in wheat, an attempt has been made to review the pertinent literature under the following headings.

\section{Effect of salinity and zinc application on crop growth}

Abou-Hadid $^{30}$ revealed that crop reduction owing to salinity is, by and large, linked to the increase in osmotic potential of the root-zone soil solution which results in certain physiological changes and a considerable decrease in productivity. Generally, wheat is classified to be moderately tolerant to salinity. Hasegawa et al. ${ }^{31}$ demonstrated that the harmful effects of salinity on plant growth are coupled with: (1) low-water potential of the root medium which triggers water deficit within the plant; (2) toxic effects primarily of $\mathrm{Na}$ and $\mathrm{Cl}$ ions and (3) nutritional imbalance produced by decreased nutrient uptake and transport to the shoot. Munns ${ }^{32}$ observed that soil salinity influenced plant growth by creating water imbalance in the plant and ionic imbalance due to the presence of toxic ions. Salt-affected plants exhibit stunted growth and have darker leaf colour. Higher carbohydrate and starch content in the salt-tolerant varieties KRL 19 and NW 1012 is probably due to better mobilization efficiency of carbohydrate and starch as a result of salinity ${ }^{33}$. Khoshgoftarmanesh et $a l .{ }^{34}$ suggested that enhanced salinity in the soil solution, particularly increased concentrations of $\mathrm{Na}^{+}$ and $\mathrm{Cl}^{-}$ions, considerably influences solubility, i.e. mobility of potentially toxic trace elements which are easily available to crop plant and negatively influence the growth and yield of a crop.

The deleterious effect of salt stress on plant growth mainly involves ion toxicity, osmotic stress and mineral deficiency ${ }^{20}$ which suppress the plant growth and alter the several physiological processes including photosynthesis, transpiration rate, chlorophyll status and relative leaf water content (RLWC\%) $)^{35,36}$. The increasing level of salinity up to $15.7 \mathrm{dS} \mathrm{m}^{-1}$ augmented the uptake of sodium and chloride ions. The increased concentration of $\mathrm{Na}$ and $\mathrm{Ca}$ ions at the high salinity level ensued in the reduction of growth of the plant ${ }^{37}$. Soil properties and crop growth were adversely affected by salinity ${ }^{38}$. Munns et al. ${ }^{39}$ observed that field conditions differ from location to location for soil salinity, physical and chemical soil characteristics. They also differ from season to season for temperature and drought, especially in dry-land agriculture, and directly influence the accrual of salts around the roots.

Mirvat et $a l .{ }^{40}$ reported that metabolism defect in plant cells is linked to zinc and phosphorus imbalance, therefore, by enhancing the concentration of phosphorus, zinc tasks are impaired at specific positions in the cells. Shoot growth is more affected than root growth. Harris et al. ${ }^{41}$ reported an increase in wheat germination, emergence and seedling growth by increasing the application of $\mathrm{Zn}$. The fact that foliar spray of $\mathrm{Zn}$ and $\mathrm{Mn}$ augmented values of germination parameters suggests that seeds with sufficient $\mathrm{Zn}$ and Mn supply can germinate and produce seedlings with improved ability to grow and endure any hostile ecological conditions. Hendawy et al. $^{42}$ showed that increasing soil salinity progressively decreased the vegetative growth characters, i.e. plant height, number of branches, fresh and dry weight of the same plants. The highest level of soil salinity (2500 ppm) caused the highest effect on vegetative growth characters. Moreover, the 
increasing level of soil salinity up to $3000 \mathrm{ppm}$ resulted in the complete death of the plant either treated or nontreated with zinc. Minakshi et al. ${ }^{43}$ reported that almost $11 \%(39,369 \mathrm{ha})$ of the total geographical area of district Patiala (Punjab) was deficient in zinc; only $4 \%$ and $5 \%$ of the area was deficient in manganese and iron, respectively, which adversely affects the growth as well as yield of the plant. Aktas et al. ${ }^{44}$ reported that $\mathrm{Zn}$ deficiency in soil significantly reduced the shoot growth, especially under the highest salt treatment. Increase in the zinc application from 2 to $10 \mathrm{mg} \mathrm{kg}^{-1}$ soil decreased the shoot concentration of $\mathrm{Na}^{+}$and elevated the $\mathrm{K}^{+}$concentration. As a result, $\mathrm{K} / \mathrm{Na}$ ratios of the plant were highest under the highest $\mathrm{Zn}$ application conditions. By affecting structural integrity and controlling the permeability of root cell membranes, sufficient $\mathrm{Zn}$ nutrition reduced excess uptake of the $\mathrm{Na}^{+}$by root in the saline conditions. It also indicates the protective role of high $\mathrm{Zn}$ supply against salt stress.

Simoglou and Dordas ${ }^{45}$ noticed a significant variation in plant height of durum wheat (Triticum turgidum L. subsp. durum Desf.) by the foliar application of $\mathrm{Zn}$ and other micronutrients. Plant height was increased by $2 \mathrm{~cm}$ due to foliar application of $\mathrm{Zn}$ than in control. Goswami ${ }^{46}$ reported an increase in grain and straw yield in addition to harvest index because of $\mathrm{Zn}$ fertilization which might be due to the fact that $\mathrm{Zn}$ plays a crucial role in the biosynthesis of indole acetic acid and the initiation of primordia for reproductive parts, on account of beneficial effect of zinc on metabolic reactions inside the plants. At the $\mathrm{EC}_{\mathrm{e}}$ $6 \mathrm{dS} \mathrm{m}^{-1}$, the growth of wheat at the boot stage decreased under both salinity levels of $\mathrm{Cl}^{-1}$ and $\mathrm{SO}_{4}^{2-}$ irrespective of $P$ level in the soil. At $\mathrm{EC}_{\mathrm{e}} 6$ and $8 \mathrm{dS} \mathrm{m}^{-1}$, the growth of wheat under $\mathrm{SO}_{4}^{2-}$ salinity was better than $\mathrm{Cl}^{-1}$ salinity particularly at 60 and $90 \mathrm{mg} \mathrm{P} \mathrm{kg}^{-1}$ soil $^{47}$. Evelin et al ${ }^{48}$ concluded that higher concentrations of soluble salt in the soils of arid and semi-arid areas negatively influence the yield of crops and all major living processes like photosynthesis, protein and lipid metabolism are also affected by excessive salts in the soil. Kamrani and Ardalan $^{49}$ reported that the simple effect of cultivar on plant height showed that the mean height of Atrak cultivar was $58.1 \mathrm{~cm}$ and for Ghods cultivar was $50.9 \mathrm{~cm}$. Increased level of applied $\mathrm{Zn}$ led to the increase in the mean height of two cultivars enhanced compared to the control, such as, in $10 \mathrm{mg} \mathrm{kg}^{-1}, 20 \mathrm{mg} \mathrm{kg}^{-1}$ and spray solution treatments the plant height was about 3.19, 5.07 and $1.31 \%$ more than control treatment respectively. Also, with increasing salinity levels, the plant height decreased.

Radi et al. ${ }^{50}$ reported that the adverse effects of salinity stress were distinctly seen in wheat and bean cultivars treated with $160 \mathrm{mM} \mathrm{NaCl}$. Rahman et al. ${ }^{51}$ suggested that the foliar-applied nutrients improve more vegetative and yield components of wheat as compared to soil-applied nutrients. Moreover, it is very useful when roots are incapable of absorbing nutrients from the soil because of interference of several edaphic factors, for instance, low soil temperature, lack of soil moisture and loss of nutrients owing to leaching. Therefore, foliar application can be viewed as a valuable practice for production of wheat. Foliar feeding of mineral nutrients at tillering, jointing, booting and various stages of the wheat crop has resulted in effective usage of nutrients and increase in yield.

\section{Effect of salinity and zinc application on physiological traits}

Chougui et al. $^{52}$ observed that the least photosynthetic ability under salt stress conditions was because of suppression of chlorophyll synthesis or decrease in the absorption of minerals needed for chlorophyll biosynthesis. Kaya et al. ${ }^{53}$ reported that micronutrients, for instance, $\mathrm{Zn}$ and $\mathrm{Mn}$, have a structural function in chlorophyll. These nutrients can be easily sprayed on the leaf. Therefore chlorophyll concentration of leaves can be enhanced by micronutrient foliar application, which successively, increases plant height and yield. Moreover, zinc increased plant height by increasing internode distances, thereby playing a crucial role in biomass production. With the addition of $\mathrm{NaCl}$, the net photosynthetic rate $\left(P_{\mathrm{N}}\right)$, stomatal conductance $\left(g_{\mathrm{S}}\right)$ and transpiration $(E)$ were reduced. Salinity increased leaf to the air temperature gradient $(\Delta T)$ in both genotypes of wheat, i.e. salttolerant (K-65) and salt sensitive (HD-2329). $\mathrm{NaCl}$ increases the activity of the superoxide dismutase (SOD) and peroxidase $(\mathrm{POX})$; the increase in an increment is higher in salt-tolerant variety of wheat ${ }^{54}$. Muranaka et $a l .{ }^{55}$ observed that under salt $(\mathrm{NaCl})$ stress, the rate of photosynthesis in wheat plants reduced in two stages. In the first stage, the photosynthetic reduction was sluggish without any apparent photochemical changes. Though, in the second stage, the photosynthetic decline was rapid and coupled with degeneration in the energy conversion efficiency in PSII. These researchers suggested that the salt-induced osmotic effect may induce a steady decline in photosynthesis owing to stomata closure under saline regimes. Nevertheless, an uptake and accrual of excessive amounts of $\mathrm{Na}^{+}$may at once affect the electron transport and cause a noticeable reduction in photosynthetic ability affecting the chlorophyll content. Hao et al. ${ }^{56}$ observed that plants with zinc application have enhanced photosynthetic rate owing to the synthesis of chloroplast, increased synthesis of chlorophyll, oxidation of water at PS-II, and predominated activities of Calvin cycle enzymes, in addition to increased absorption of $\mathrm{CO}_{2}$ as a result of stomatal opening and increased nutrient uptake. Alpaslan et al. ${ }^{57}$ suggested that zinc has controlled mechanism or a regulatory role on the $\mathrm{Na}^{+}$and $\mathrm{Cl}^{-}$uptake and translocation rate. They also concluded that in the salt-affected soils, zinc application could abate possible $\mathrm{Na}^{+}$and $\mathrm{Cl}^{-}$injury in the plant. Salinity-induced reductions in $\mathrm{P}$ concentrations in plant tissues were often reported in research conducted in soil conditions. 
Chen et $a l .^{58}$ reported that zinc deficiency caused a drastic reduction in chlorophyll content in addition to severe damage to the fine structure of the chloroplast. The total chlorophyll content and other growth parameters such as plant height, plant fresh and dry weight and leaf area as well as N, P and K content were decreased as the salinity level increased and salinity effect can be reduced by zinc application and gave positive effect on plant growth parameters ${ }^{59,60}$. Cakmak ${ }^{61}$ demonstrated from his study that foliar nutrition is an alternative when nutrient deficiencies cannot be corrected by the application of nutrients to the soil. Zinc also plays a significant role in the production of biomass. Moreover, zinc may be required for chlorophyll synthesis, pollen function, fertilization and germination. Salt stress decreases the chlorophyll content; however, the degree of reduction depends on salt tolerance of that plant. By and large, it is known that in salt-tolerant crops such as wheat, chlorophyll content increases, while on the contrary, it decreases in salt-sensitive species or crops under saline regimes or conditions $^{62}$. Saeidnejad et al. ${ }^{63}$ ascertained that salinity causes a significant reduction in chlorophyll $a$ and $b$ content. However, the activity of catalase (CAT), superoxide dismutase (SOD) and glutathione reductase (GR) increased as the salinity level was enhanced. Addition of zinc alleviated the significant enhancement of $\mathrm{Na}^{+}$concentration caused due to salinity.

Rani et al. ${ }^{64}$ reported that under salinity there was a considerable decrease in dry weight of roots and micronutrient ( $\mathrm{Zn}, \mathrm{Cu}, \mathrm{Fe}$ and $\mathrm{Mn})$ uptake. The adverse effect of saline environment was ameliorated by $\mathrm{Zn}$ applications and for that optimum dose of $\mathrm{Zn}$ application in both types of salinity was $15 \mathrm{mg} \mathrm{kg}^{-1}$ soil. Moreover, root dry weight and micronutrient uptake ( $\mathrm{Zn}, \mathrm{Cu}, \mathrm{Fe}$ and $\mathrm{Mn}$ ) have a negative interaction with increasing salinity and positive interaction with the increasing application of $\mathrm{Zn}$. Bagayoko et al. ${ }^{65}$ demonstrated an important method for enhancing $P$ uptake which involves taking advantage of the symbiosis between the mycorrhiza and roots and, the former of which increases both the growth and resistance of plants exposed to drought, and also the uptake of $\mathrm{P}$, $\mathrm{Zn}, \mathrm{Cu}, \mathrm{Mn}$ and $\mathrm{Fe}$. Wheat with different levels of zinc influences the concentration of micronutrients $(\mathrm{Zn}, \mathrm{Cu}$, $\mathrm{Fe}$ and $\mathrm{Mn}$ ) in several parts of the plant and it was also observed that the zinc content in various parts of wheat increased with increased levels of zinc application ${ }^{66}$. ElFouly et al. ${ }^{67}$ observed that foliar spraying of micronutrients may somewhat counteract the negative effect of $\mathrm{NaCl}$ on nutrient uptake by improving root growth and preventing disorders and as a result, caused an increase in the uptake of nutrients by the roots. Hu and Schmidhal$\operatorname{ter}^{68}$ reported that salinity stress also induces ion deficiency or imbalance owing to the competition of nutrients, for example $\mathrm{K}^{+}, \mathrm{Ca}^{2+}$ and $\mathrm{NO}_{3}^{-}$with the toxic ions $\mathrm{Na}^{+}$and $\mathrm{Cl}^{-}$. The higher $\mathrm{K}^{+}: \mathrm{Na}^{+}$will also improve the resistance of plant to salinity. Calcium is a key signal messenger for regulating plant resistance to salinity, the competition between $\mathrm{Cl}^{-}$and $\mathrm{NO}_{3}^{-}$under saline conditions means that the form of $\mathrm{N}$ plays a crucial role in deciding the growth of salinized plants.

Tabatabaei ${ }^{69}$ observed that under saline conditions nutrient absorption is constrained by lack of nutrients and low water potential in the rooting medium. The results are in conformity with those reported by Murat et al. ${ }^{70}$ who stated that application of $\mathrm{NaCl}$ caused a reduction in $\mathrm{N}, \mathrm{K}, \mathrm{Zn}$ and other micronutrient concentrations. Such an effect may be ascribed to the effect of salinity on nutrient absorption. Abd-El and Hady ${ }^{71}$ examined the effect of zinc application on growth and nutrient uptake of barley irrigated with saline water and stated that $\mathrm{Zn}$ content of the fresh and dry weight enhanced with increasing $\mathrm{Zn}$ rate at various salinity levels as compared to control and the amount of nutrient elements significantly decreased by increasing salinity. Chang et al. ${ }^{72}$ demonstrated that zinc mobility and uptake in soil is dependent on various factors, for instance soil acidity, zinc total value in the soil, organic matter, soil type and phosphorus levels in the soil. The most important factor which affects zinc usability is the soil $\mathrm{pH}$. The yield of wheat increased from 3.40 to $4.35 \mathrm{t} \mathrm{ha}^{-1}$ and $\mathrm{Zn}$ uptake increased from 142 to $256 \mathrm{~g} \mathrm{ha}^{-1}$ with long-term application of crop residues together with $\mathrm{Zn}$ by using appropriate rates, methods (soil) and sources (such as $\mathrm{ZnSO}_{4}$ ). Although there are several sources of $\mathrm{Zn}$, the most common source of $\mathrm{Zn}$ remains $\mathrm{ZnSO}_{4}$ (ref. 73). Saeidnejad et $a l .{ }^{63}$ reported that potassium content was increased by $\mathrm{Zn}$ treatments. A considerable increase was noticed in leaf $\mathrm{Zn}$ concentration as the applied level of $\mathrm{Zn}$ was increased. By and large, the results suggest some positive and negative interactions of salinity and $\mathrm{Zn}$ application, which could be useful in the management of saline soil and water.

\section{Effect of salinity and zinc application on crop yield attributes}

Tuna et al. ${ }^{74}$ suggested that shoot and root growth inhibition is a common response to salinity. Plant growth is one of the most crucial agricultural indices of salt stress tolerance as suggested by certain studies. The dry matter yield of root and shoot systems of the crop showed a noticeable decrease as salinity levels increased. Salama et al. $^{75}$ observed that with every increase in saline water levels of $2000 \mathrm{ppm}$ the negative effect on total yield is assigned to the adverse effect of salinity on leaf area, total chlorophyll content, NPK content in leaves and fruit setting which may consequently lead to reduced total yield. Morshedi and Farahbakhsh ${ }^{76}$ observed that yield components, grain yield and protein content of the two genotypes (Line no. 4 and Backcrossroshan) increased linearly as the levels of $\mathrm{K} \times \mathrm{Zn}$ interaction treatments increased. Line no. 4 produced 1000-grain weight, the weight of grains per ear and grain yield greater than Backcrossroshan 


\section{REVIEW ARTICLES}

by 17,30 and $23 \%$ respectively. Moreover, a significant relationship between grain weight per ear and grain yield was observed. As a result, line no. 4 is more productive under salinity and alkalinity of soil and water.

Micronutrient application significantly affected plant height, number of spikes per plant, number of grains per spike, 1000-grain weight, grain yield, biological yield and harvest index. Application of micronutritious elements especially manganese, zinc and iron alone or in a combination of manganese and iron significantly increased yield and yield components. Therefore, it can be concluded that micronutrient application had a positive effect on wheat growth and yield ${ }^{77}$. As the application of $\mathrm{Zn}$ increases, the concentration of $\mathrm{Zn}$ in the shoots and grains increases significantly. Grain protein was decreased by salinity, while the utilization of grain protein enhanced and finally improved the growth and yield of wheat by decreasing the effects of salinity, therefore the addition of $\mathrm{Zn}$ helped in reducing the unfavourable effects of increased salinity tolerance of wheat to salinity ${ }^{78}$. Keram et al. ${ }^{79}$ observed that the treatment with $10 \mathrm{~kg} \mathrm{Zn} \mathrm{ha}^{-1}$ was statistically at par to $20 \mathrm{~kg} \mathrm{Zn} \mathrm{ha} a^{-1}$ in grain $\left(4.62 \mathrm{t} \mathrm{ha}^{-1}\right)$ and straw $\left(5.42 \mathrm{t} \mathrm{ha}^{-1}\right)$ yield and harvest index $(46.07 \%)$. The lowest grain $\left(3.88 \mathrm{t} \mathrm{ha}^{-1}\right)$ and straw $\left(4.76 \mathrm{t} \mathrm{ha}^{-1}\right)$ yield in addition to harvest index (44.97\%) was registered in control. The treatments consisting 1.25, 2.50 and $5 \mathrm{~kg} \mathrm{Zn} \mathrm{ha}{ }^{-1}$ were at par with control in grain and straw, correspondingly, whereas the harvest index was inferior and nonsignificant with all the treatments.

Khoshgoftar et al. ${ }^{80}$ observed that growth and yield of wheat plants significantly decreased with increasing $\mathrm{NaCl}$ rate and $\mathrm{Zn}$ application increased dry weight yield at different levels of salinity. Application of $\mathrm{Zn}$ fertilizer somewhat counteracted the negative effects of salinity on plant growth. Amador et $a l^{81}$ found that biomass declined more severely at $170 \mathrm{mM} \mathrm{NaCl}$ compared to $85 \mathrm{mM} \mathrm{NaCl}$ in all groups of cowpea genotypes and diminished as salinity increased. Ali et al. ${ }^{82}$ concluded from the experiment that solutions of zinc, boron and zinc plus boron were used as a foliar spray, each applied at tillering, jointing and boot stage. A significant increase was noticed in the number of spikes per metre square, grains per spike, thousand-grain weight, biological yield and grain yield for foliar application of zinc and boron in comparison to both control treatments. In India, 10\% yield loss is reported due to the omission of $\mathrm{Zn}$ fertilization $^{83}$. Khan et al. $^{84}$ accomplished a field experiment to test the response of wheat to market available micronutrient application 'Shelter' (zinc $=2 \%$, iron $=1 \%$, manganese $=2 \%, \quad$ copper $=1 \%, \quad$ boron $=1 \%$ ). Shelter treatment significantly increased the number of grains per spike, 1000 grain weight, straw yield, grain yield, biological yield and harvest index at various growth stages of wheat. Lastly, the commercially available foliar application may be beneficial to improve the growth as well as yield of wheat. Yassen et al. ${ }^{85}$ executed experiments to study the response of wheat, its yield, and growth to foliar spraying with (1\%) urea and different applications of micronutrients (Fe, $\mathrm{Zn}$ and $\mathrm{Mn}$ ). The results showed that foliar spray of $1 \%$ urea gave significantly higher 1000 -grain weight whereas the interaction effect of micronutrients spraying and $1 \%$ urea revealed affirmative results on all the attributes and showed a significant increase in grain and straw yields.

$\mathrm{Lu}$ et $a l .{ }^{86}$ observed that the joint application of $\mathrm{P}$ and $\mathrm{Zn}$ enhanced the diethyltriaminepenta acetic acid-Zn and loose organic matter bound $\mathrm{Zn}$; however, the increase becomes smaller as the $\mathrm{P}$ fertilizer application rate increased. The addition of $\mathrm{Zn}$ fertilizer to $\mathrm{Zn}$-deficient soils can increase or improve the nutritional attributes of wheat grain, grain $\mathrm{Zn}$ concentration and biodiversity. Bameri et $a l{ }^{77}$ showed in his experiment that micronutrient application significantly affected plant height, number of grains per plant, number of grains per spike, weight of 1000grains, grain yield, biological yield and harvest index. Srinivasarao and $\mathrm{Rani}^{87}$ observed that the foliar application of $\mathrm{Zn}$ is the significant preventive measure of $\mathrm{Zn}$ deficiency symptoms in crops and has a substantial effect on yield and quality of production. Soil and foliar application in conjunction with organic manure (FYM, incorporation of green leaf manuring, composts, tank silt, etc.) are efficient in ameliorating $\mathrm{Zn}$ deficiency disorders. Screening of cultivars of most of the crop species for $\mathrm{Zn}$ efficient strains decreases the necessity for $\mathrm{Zn}$ fertilizers.

\section{Conclusion}

Salinity is a major abiotic stress that reduces and endangers agricultural productivity in various parts of the globe. Salinity has inhibitory effects on physiological aspects of wheat which impair the growth and yield of the crop. Zinc application can increase both quantitative and qualitative traits of wheat when applied properly. Also, zinc application reduces the negative effect of salinity on crop growth and yield. From the literature, it is evident that combination of salinity and $\mathrm{Zn}$ caused a broad range of physiological response in wheat plants, which alleviate the detrimental effects of stress and these outcomes might be regarded as a nutrient management tool, particularly for plants under salinity stress.

1. Rengasamy, P., World salinization with emphasis on Australia. J. Exp. Bot., 2006, 57, 1017-1023.

2. Shrivastava, P. and Kumar, R., Soil salinity: A serious environmental issue and plant growth promoting bacteria as one of the tools for its alleviation. Sau. J. Biol. Sci., 2015, 22, 123-131.

3. Paranychianakis, N. V. and Chartzoulakis, K. S., Irrigation of Mediterranean crops with saline water: From physiology to management practices. Agric. Eco. Environ., 2005, 106, 171-187.

4. He, L., Ban, Y., Inoue, H., Matsuda, N., Liu, J. and Moriguchi, T., Enhancement of spermidine content and antioxidant capacity in transgenic pear shoots over expressing apple spermidine synthase in response to salinity and hyperosmosis. Phytochemistry, 2008, 69, 2133-2141. 
5. Akhter, J., Murray, R., Mahmood, K., Malik, K. A. and Ahmed, $\mathrm{S}$., Improvement of degraded physical properties of a saline-sodic soil by reclamation with kallargrass (Leptochloa fusca). Plant Soil, 2004, 258, 207-216.

6. Jouyban, Z., The effects of salt stress on plant growth. Tech. J. Eng. App. Sci., 2012, 2, 7-10.

7. Muhammad, Z., Hussain, F., Rehmanullah, R. and Majeed, A., Effect of halopriming on the induction of $\mathrm{NaCl}$ salt tolerance in different wheat genotypes. Pak. J. Bot., 2015, 47, 1613-1620.

8. FAO, Global network on integrated soil management for sustainable use of salt-affected soils, 2002; http://www.fao.org/ag/AGL/ agll/spush/intro.html

9. Jamil, A., Riaz, S., Ashraf, M. and Foolad, M. R., Gene expression profiling of plants under salt stress. Cri. Rev. Plant Sci., 2011, 30, 435-458.

10. Hasanuzzaman, M. et al., Potential use of halophytes to remediate saline soils. Biol. Med. Res. Inter., 2014, 1-12.

11. Menason, E., Betty, T., Vijayan, K. K. and Anbudurai, P. R., Modification of fatty acid composition in salt adopted Synechocystis 6803 cells. Ann. Bio. Res., 2015, 6, 4-9.

12. ICAR-Central Soil Salinity Research Institute, Vision 2050 at www.cssri.org

13. Zhao, J., Ren, W., Zhi, D., Wang, L. and Xia, G., Arabidopsis DREB1A/CBF3 bestowed transgenic tall rescue increased tolerance to drought stress. Plant Cell Rep., 2007, 26, 1521-1528.

14. Bauder, J. W. and Brock, T. A., Irrigation and quality, soi amendment and crop effects on sodium leaching. Arid Land Res. Manage., 2001, 15, 1101-1133.

15. Dikilitas, M. and Karakas, S., Behavior of plant pathogens for crops under stress during the determination of physiological, biochemical and molecular approaches for salt stress tolerance. In Crop Production for Agricultural Improvement (ed. Ashraf, M.), Heidelberg, Germany, Springer, New York, 2012, pp. 417-441.

16. Taiz, L. and Zeiger, E., Plant Physiology, Sinauer, Sunderland, UK, 2002, 3rd edn, p. 690.

17. Munns, R. et al., Avenues for increasing salt tolerance of crops, and the role of physiologically based selection traits. Plant Soil, 2002, 247, 93-105.

18. Francisco, G., Jhon, L., Jifon, S., Micaela, C. and James, P. S., Gas exchange, chlorophyll and nutrient contents in relation to $\mathrm{Na}^{+}$ and $\mathrm{Cl}^{-}$accumulation in sunburst mandarin grafted on different root stocks. Plant Sci., 2002, 35, 314.

19. Jiang, M. and Zhang, J., Effect of abscisic acid on active oxygen species, anti oxidative defense system and oxidative damage in leaves of maize seedlings. Plant Cell Physiol., 2001, 42, 12651273 .

20. Ashraf, M. and Harris, P. J. C., Potential biochemical indicators of salinity tolerance in plants. J. Plant Sci., 2004, 166, 3-16.

21. Khan, N. A., NaCl-inhibited chlorophyll synthesis and associated changes in ethylene evolution and antioxidative enzyme activities in wheat. Biol. Plant., 2003, 47, 437-440.

22. Munns, R., Comparative physiology of salt and water stress. Plant Cell Environ., 2002, 25, 239-250.

23. Parida, A. K. and Das, A. B., Salt tolerance and salinity effects on plants: A Rev. Econ. Environ. Saf., 2005, 60, 324-349.

24. Arzani, A., Improving salinity tolerance in crop plant: a biotechnological view. In vitro Cell Dev. Biol. Plant., 2008, 44, 373383 .

25. Alloway, B. J., Zinc in soils and crop nutrition. IZA, Brussels, Belgium and IFA, Paris, France, 2008, 2nd edn.

26. Maischner, H., Mineral Nutrition of Higher Plants, Academic Press, San Diogo, CA, 2002, 2nd edn, p. 355.

27. Mousavi, S. R., Zinc in crop production and interaction with phosphorus. Aus. J. Basic App. Sci., 2011, 5(9), 1503-1509.

28. Sarkar, D., Mandal, B. and Kundu, M. C., Increasing use efficiency of boron fertilizers by rescheduling the time amendment of application for crop in India. Plant Soil, 2007, 301, 77-85.
29. Singh, D., Ram, P. C., Singh, A., Dar, S. R. and Srivastava, J. P., Alleviation of soil salinity by zinc fertilizer in wheat. Plant Arc., 2013, 13(1), 311-316.

30. Abou-Hadid, A. F., The use of saline water in agriculture in the Near East and North Africa region: present and future. J. Crop Prod., 2003, 7(1/2), 299-323.

31. Hasegawa, P. M., Bressan, P. A., Zhu, J. and Bohnert, H. J., Plant cellular and molecular responses to high salinity. Annu. Rev. Plant Physiol. Plant Mol. Biol., 2000, 51, 463-499.

32. Munns, R., In Salt Affected Soils and Crop Production: A Modern Synthesis (ed. Lal, P.), Agrobios Publishers, Jodhpur, India, 2003, pp. 296-315.

33. Roy, N. K. and Srivastava, A. K., Effect of salt stress on seedling growth and carbohydrate content in wheat. Int. J. Plant Physiol., 2001, 37, 363-376.

34. Khoshgoftarmanesh, A. H., Shariatmadari, H., Karimian, N., Kalbasi, M. and Vanderzee, S. E. A. T. M., Cadmium and zinc in saline soil solutions and their concentrations in wheat. Soil Sci. Soc. Am. J., 2006, 70, 582-589.

35. Nandwal, A. S., Godara, M., Kamboj, D. V., Kundu, B. S., Mann, A., Kumar, B. and Sharma, S. K., Nodule functioning in trifoliate and pentafoliate mungbean genotypes as influenced by salinity. Biol. Plant., 2000, 43(3), 459-308.

36. Kukreja, S., Nandwal, A. S., Kumar, N., Sharma, S. K., Sharma, S. K. and Univ, V., Plant water status, $\mathrm{H}_{2} \mathrm{O}_{2}$ scavenging enzymes, ethylene evolution and membrane integrity of Cicer arietinum roots as affected by salinity. Biol. Plant., 2005, 49(2), 305-308.

37. Sharma, S. K., Effect of salinity in uptake and distribution of $\mathrm{Na}$, $\mathrm{Cl}$ and $\mathrm{K}$ in two cultivars. Biol. Plant., 1996, 38, 261-267.

38. Singh, S. and Singh, M., Genotypic basis of response to salinity stress in some crosses of spring wheat (Triticum aestivum L.). Euphytica, 2000, 115, 209-219.

39. Munns, R., James, R. A. and Lauchli, A., Approaches to increasing the salt tolerance of wheat and other cereals. J. Exp. Bot., 2006, 57, 1025-1043.

40. Mirvat, E. G., Mohamed, M. H. and Tawfik, M. M., Effect of phosphorus fertilizer and foliar spraying with zinc on growth, yield and quality of groundnut under reclaimed sandy soils. J. App. Sci. Res., 2006, 2(8), 491-496.

41. Harris, D., Rashid, A., Miraj, G., Arif, M. and Yunas, M., 'On-farm' seed priming with zinc in chickpea and wheat in Pakistan. Plant Soil, 2008, 306, 3-10.

42. Hendawy, S. F. and Khalid, K. A., Response of sage (Salvia officinalis L.) plant to zinc application under different salinity levels. J. Appl. Sci. Res., 2005, 1(2), 147-155.

43. Minakshi, Tur, N. S., Nayyar, V. K., Sharma, P. K. and Sood, A. K., Spatial distribution of micronutrients in soils of Patiala district - a GIS approach. J. Indian Soc. Soil Sci., 2005, 53, 324-329.

44. Aktas, H., Mabak, K., Osturk, L. and Cakmak, S., The effect of zinc on the growth and shoot concentrations of sodium and potassium in pepper plants under salinity stress. Turk. J. Agric. Foru., 2006, 30, 407-412.

45. Simoglou, K. B. and Dordas, C., Effect of foliar applied boron, manganese and zinc on tan spot in winter durum wheat. Crop Prot., 2006, 25, 657-663.

46. Goswami, Response of wheat (Triticum aestivum) to nitrogen and zinc application. Ann. Agric. Res., New Ser., 2007, 28(1), 90-91.

47. Sharma, S. K., Manchanda, H. R. and Kapoor, A. K., Phosphorus requirement of wheat under chloride and sulphate dominated salinity. J. Indian Soc. Soil Sci., 2007, 55(4), 509-514.

48. Evelin, H., Kapoor, R. and Giri, B., Arbuscular mycorrhizal fungi in alleviation of salt stress: a review. Ann. Bot., 2009, 104, 12631281.

49. Kamrani, R. and Ardalan, M. A., A study on the growth and concentration of $\mathrm{Zn}, \mathrm{Mn}$ and $\mathrm{Na}$ by two wheat cultivars in response to application of $\mathrm{Zn}$ in natural saline soils. Int. Res. J. App. Basic Sci., 2013, 7(13), 1025-1033. 


\section{REVIEW ARTICLES}

50. Radi, A. A., Farghaly, F. A. and Hamada, A. M., Physiological and biochemical responses of salt-tolerant and salt-sensitive wheat and bean cultivars to salinity. J. Biol. Earth Sci., 2013, 3(1), 72-88.

51. Rahman, I. U. R., Afzal, A., Iqbal, Z. and Manan, S., Foliar application of plant mineral nutrients on wheat: a review. Res. Rev.: J. Agric. All. Sci., 2014, 3(2), 19-22.

52. Chougui, S., Yaklef, N. and Hamid, A. D., Interaction iron-salinity. 1. Relation of photo synthesis $/ \mathrm{K}+$ (roots) with other morphological, physiological, and biochemical aspects of tomato (Lycopersicon esculentium Mill). J. Agric. Sci., 2004, 12(2), 481-497.

53. Kaya, C., Higgs, D. and Burton, A., Phosphorus acid phosphates enzyme activity in leaves of tomato cultivars in relation to $\mathrm{Zn}$ supply. Commun. Soil Sci. Plant Anal., 2002, 31, 3239-3248.

54. Sharma, N., Gupta, N. K., Gupta, S. and Hasegawa, H., Effect of $\mathrm{NaCl}$ salinity on photosynthetic rate, transpiration rate and oxidative stress tolerance in contrasting wheat genotypes. Photosynthesis, 2005, 43, 609-613.

55. Muranaka, S., Shimizu, K. and Kato, M., A salt-tolerant cultivar of wheat maintains photosynthetic activity by suppressing sodium uptake. Photosynthesis, 2002, 40, 509-515.

56. Hao, M. D., Wei, D. V. and Dang, V., Effect of long-term applying zinc fertilizer on wheat yield and content of zinc in dry land. Plant Nutr. Fert. Sci., 2003, 9(3), 377-380.

57. Alpaslan, M., Inal, A., Gunes, A., Cikili, Y. and Özcan, H., Effect of zinc treatment on the alleviation of sodium and chloride injury in tomato (Lycopersicum esculentum (L.) Mill. cv. Lale) grown under salinity. Turk. J. Bot., 1999, 23, 1-6.

58. Chen, H. J., Chen, Y. J. and Wang, S. J., Molecular regulation of starch accumulation in rice seedling leaves in responses to the salt stress. Acta Physiol. Plant., 2007, 30, 135-142.

59. Tantawy, A. S., Effect of some mineral and organic compounds on salinity tolerance in tomato. Ph D thesis. Al-Azhar University, 2007.

60. Babu, M. A., Singh, D. and Godhanddam, K. M., The effect of salinity on growth, hormones and mineral elements in leaf and fruit of tomato cultivar PKM1. J. Anim. Plant Sci., 2012, 22(1), 159-164.

61. Cakmak, I., Enrichment of cereal grains with zinc: agronomic or genetic biofortification. Plant Soil., 2008, 302, 1-17.

62. Khan, M. A., Shirazi, M. U. and Khan, M. A., Role of proline, $\mathrm{K} / \mathrm{Na}$ ratio and chlorophyll content in salt tolerance of wheat (Triticum aestivum L.). Pak. J. Bot., 2019, 41, 633-638.

63. Saeidnejad, A. H., Kafi, M. and Pessarakli, M., Interactive effects of salinity stress and $\mathrm{Zn}$ availability on physiological properties, antioxidant activity, and micronutrients content of wheat (Triticum aestivum) plants. Commun. Soil Sci. Plant Anal., 2016, 47(8), 1048-1057.

64. Rani, S., Sharma, M. K. and Rani, P., Zinc nutrition influences growth and micronutrient uptake of wheat root under saline environments. Veg., 2017, 30, 248-252.

65. Bagayoko, M., George, E., Römheld, V. and Buerkert, A. B., Effects of mycorrhizae and phosphorus on growth and nutrient uptake of millet, cowpea and sorghum on a West African soil. J. Agric. Sci., 2000, 135, 399-407.

66. Sharma, B. L. and Bapat, P. N., Levels of micronutrient cations in various plant parts of wheat are influenced by zinc and phosphorus application. J. Indian Soc. Soil Sci., 2000, 48, 130-134.

67. El-Fouly, M. M., Mobarak, Z. M. and Salama, Z. A., Micronutrient foliar application control salination for horticultural productivity. Acta Hort., 2002, 573, 377-385.

68. $\mathrm{Hu}, \mathrm{Y}$. and Schmidhalter, U., Drought and salinity: a comparison of their effects on mineral nutrition of plants. J. Plant Nutr. Soil Sci., 2005, 168, 541-549.

69. Tabatabaei, S. J., Effect of salinity and non growth, photosynthesis, and N status of olive (Olea europaea L.) trees. Sci. Hort., 2006, 108, 432-438.

70. Murat, A. T., Katkat, V. and Suleyman, T., Variations in proline, chlorophyll and mineral elements contents of wheat plants grown under salinity stress. J. Agron., 2007, 6(1), 137-141.
71. Abd-El and Hady, B. A., Effect of zinc application on growth and nutrient uptake of barley plant irrigated with saline water. J. Appl. Sci. Res., 2007, 3(6), 431-436.

72. Chang, W. Y. et al., Sufficiency and deficiency indices of soil available zinc for rice in the alluvial soil of the coastal yellow sea. Rice Sci., 2007, 14(3), 223-228.

73. Prasad, R. K., Kumar, V., Prasad, B. and Singh, A. P., Long-term effect of crop residues and zinc fertilizer on crop yield, nutrient uptake and fertility build-up under rice-wheat cropping system in calciorthents. J. Indian Soc. Soil Sci., 2010, 58, 205-211.

74. Tuna, A. L., Kaya, C., Dikilitas, M. and Higgs, D., The combined effects of gibberellic acid and salinity on some antioxidant enzyme activities, plant growth parameters and nutritional status in maize plants. Environ. Exp. Bot., 2008, 62, 1-9.

75. Salama, Y. A. M., Nagwa, M. K. H., Saleh, S. A. and Zaki, M. F., Zinc ameliorate effect on tomato growth and production under saline water irrigation conditions. J. Appl. Sci. Res., 2012, 8(12), 5877-5885.

76. Morshedi, A. and Farahbakhsh, H., Effects of potassium and zinc on grain protein contents and yield of two wheat genotypes under soil and water salinity and alkalinity stresses. Plant Ecophys., 2010, 2, 67-72.

77. Bameri, M., Abdolshahi, R., Nejad, G. M., Yousefi, K. and Tabatabaie, S. M., Effect of different microelement treatment on wheat (Triticum aestivum) growth and yield. Int. Res. J. App. Basic Sci., 2012, 3(1), 219-223.

78. Kamrani, R., Ardalan, M. and Farahbakhsh, M., The interaction $\mathrm{Zn}$ application and salinity on the yield and zinc concentration in grain wheat. Int. J. Agro. Plant Prod., 2013, 4(8), 2075-2080.

79. Keram, K. S., Sharma, B. L. and Sawarkar, S. D., Impact of Zn application on yield, quality, nutrients uptake and soil fertility in a medium deep black soil (vertisol). Int. J. Sci. Environ. Tech., 2012, 1(5), 563-571.

80. Khoshgoftar, A. H., Shariatmadari, N., Karimian, M. and Kalbasi, M., Salinity and zinc application effects on phytoavailability of cadmium and Zinc. Soil Sci. Soc. Am. J., 2004, 68, 1885-1889.

81. Amador, M. B., Troyo-Dieguez, E., Garcia-Hernandez, J. L., Lopez-Aguilar, R., Avila-Serrano, N. Y. and Zamra-Salgado, S., Effect of $\mathrm{NaCl}$ salinity in the genotypic variation of cowpea (Vigna unguiculata) during early vegetative growth. Sci. Hortic., 2006, 108, 432-431.

82. Ali, S., Shah, A., Arif, M., Miraj, G., Ali, I., Sajjad, M., Farhatullah, Khan, Y. M. and Khan, M. N., Enhancement of wheat grain yield and yield components through foliar application of zinc and boron. Sar. J. Agric., 2009, 25(1).

83. Shukla, A. K., Dwivedi, B. S., Singh, V. K. and Gill, M. S., Macro role of micro nutrients. Indian J. Fert., 2009, 5(5), 11-30.

84. Khan, B. M., Farooq, M., Hussain, M., Shahnawaz and Shabirg, Foliar application of micronutrients improves the wheat yield and net economic return. Int. J. Agric. Biol., 2010, 12, 953-956.

85. Yassen, A., El-Nour, A. A. and Shedeed, S., Response of wheat to foliar spray with urea and micronutrients. J. Am. Sci., 2010, 6(9), 14-22.

86. Lu, X., Tian, X., Cui, J., Zhao, A., Yang, X. and Mai, W., Effect of combined phosphorus-zinc on grain zinc nutritional quality of wheat grown on potentially zinc deficient calcareous soils. Soil Sci., 2011, 176, 684-690.

87. Srinivasarao, C. and Rani, S. Y., Zinc deficiency: a productivity constraint in rainfed crop production systems of India. J. SAT Agric. Res., 2013, 11.

Received 12 June 2018; revised accepted 30 October 2018

doi: $10.18520 / \mathrm{cs} / \mathrm{v} 116 / \mathrm{i} 8 / 1324-1330$ 